
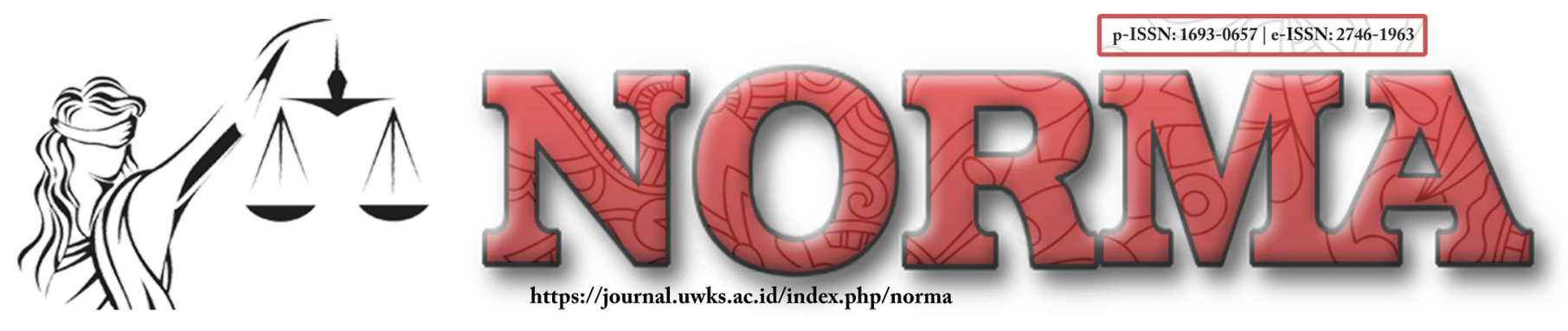

\title{
Diversion's Application in The Juvenile Justice System to Realize Restorative Justice Related to Deprivation of Liberty Principle
}

\author{
Aunur Rofiq \\ Judge at Lamongan District Court \\ e-Mail: cak.ophick@gmail.com
}

\begin{abstract}
:
Diversion Efforts can only be carried out in cases of Children in conflict with laws that threaten their crimes under 7 (seven) years and do not constitute a repeat of a criminal act. In contrast, the juvenile justice system requires deprivation of liberty principle and punishment related to the latest findings. This research uses the normative legal research method, using the law method, research method, and comparative method. From this research, we know that diversion in the juvenile justice system cannot be done in every child's case; it can only be done in the case of children who meet the requirements of a case protected under 7 (seven) a repeat of follow up. Not all cases of children go through a process of diversion. Children who have a conflict with the law are directly threatened with criminal punishment. However, there has been a reconciliation between the perpetrators and the victims, so that the deprivation of liberty principle, and criminalization, is the latest result, which is not successful. Therefore, diversion shall not be used again to protect children.
\end{abstract}

Keywords: Diversion, Children, Liberty.

\author{
Article's History: \\ Received: \\ 6 November, 2020; \\ Received in revised form: \\ 10 February, 2021; \\ Accepted: \\ 10 February, 2021; \\ Published: \\ 10 February, 2021. \\ DOI:
}

10.30742/nlj.v17i3.1075

\section{INTRODUCTION}

As a manifestation of the commitment of the State of Indonesia as stipulated in the 1945 Constitution of the Republic of Indonesia, formulated in Article 28 B paragraph (2), in terms of providing protection for children and upholding children's rights, the Government of the Republic of Indonesia has ratified the Convention on the Rights of the Child) by Presidential Decree Number 36 of 1990 concerning Ratification of the Convention on the Rights of the Child.

The term Naughty Child is no longer used after enacting Law Number 11 of 2012 concerning the Criminal Justice System for Children, so the name has changed from Naughty Children to Children Facing the Law (ABH). Currently, Law Number 11 of 2012 concerning the Criminal Justice System for Children uses the term for a child who commits a criminal act as a child in conflict with the law. Law Number 11 of 2012 concerning the Juvenile Criminal Justice System replaces Law Number 3 of 1997 
concerning Juvenile Court, which is no longer following society's development and legal needs. It has not comprehensively protected children who conflict with the law.

The most basic substance regulated in Law Number 11 of 2012 concerning the Juvenile Criminal Justice System is tight regulation regarding Restorative Justice and Diversion. According to the concept of Restorative Justice, the recovery process is through diversion, namely the transfer or transfer of the judicial process into an alternative method of solving criminal cases, namely through deliberation on recovery or mediation. The transfer step is made to prevent the child from further legal action. Besides that, the transfer aims to avoid the negative influence of the next legal action that can cause stigmatization for community support.

Diversion is currently considered a process recognized internationally as the best and most effective way of resolving cases of children in conflict with the law. This thought initially arose because children were influenced by several other factors outside of the child, such as relationships, education, family, playmates, etc. Diversion aims to achieve peace between victims and children, resolve cases of children outside the judicial process, prevent children from being deprived of liberty, encourage people to participate, and instill a sense of responsibility in children. Diversion must be carried out at every stage from the investigation, prosecution, and examination at the District Court. Diversion is said to be successful if there is an agreement, and the case can be stopped. Restorative justice is achieved, whereas if the diversion is not successful, then the issue is continued until the child is convicted.

Children are not to be punished but must be given guidance and guidance to grow and develop as normal children who are completely healthy and intelligent. Children are a gift from Allah Almighty as candidates for the next generation of the nation who are still in physical and mental development. Sometimes children experience difficult situations that make them commit illegal acts. However, children who break the law are not eligible to be punished, let alone put in prison.

In the imposition of punishment, although the sentence imposed on children can be a warning or a criminal with conditions, stigmatization as a child who has served a sentence is inherent in the child who conflicts with the law. For the sake of legal protection for children who clash with the law, especially children who conflict with the law, with due observance of the principles in the Juvenile Criminal Justice System, all cases of children without exception can be carried out for diversion so that deprivation of liberty and punishment is the last resort.

\section{PROBLEM FORMULATION}

Does the application of diversion in the Juvenile Criminal Justice System achieve Restorative Justice reflect the principle of deprivation of liberty and punishment as a last resort? 


\section{RESEARCH METHOD}

This research is normative legal research with statutory approach.

\section{DISCUSSION}

The Juvenile Court Law's implementation is positioned as an object, and the treatment of children in conflict with the law tends to harm the child. The Juvenile Court Law only protects children as victims, while children as perpetrators are sometimes positioned the same as adult perpetrators. Besides, the law is no longer following the legal needs in society and has not comprehensively provided superior protection for children who are faced with the law. Thus, there is a need for a paradigm shift. To make a paradigm shift in the handling of children who are faced with the law based on the roles and duties of the community, government, and other state institutions that are obliged and responsible for improving the welfare of the child and providing superior protection to children who conflict with the law, then to create a judiciary that is proper guarantees the safety of the best interests of children who are faced with the law as the successor of the nation so that the Indonesian government then established Law Number 11 of 2012 concerning the Juvenile Criminal Justice System (from now on referred to as SPPA Law) replacing Law Number 3 of 1997 concerning Children's Courts.

The most basic substance in this law is strict regulation regarding Restorative Justice and Diversion, which is intended to avoid and keep children away from the judicial process to prevent stigmatization of children who conflict with the law. It is hoped that the child can reasonably return to the social environment. The child is in a difficult situation that makes him commit illegal acts. However, children who break the law are not eligible to be punished, let alone be put in prison, a paradigm shift from an emphasis on retributive justice and an emphasis on restitutive justice to emphasize restorative justice. The focus on restorative justice must be supported by the roles and duties of the community, government, and other state institutions that are obliged and responsible for improving the welfare of children and providing superior protection for children who conflict with the law.

The Indonesian Criminal Law System has entered a new chapter in its development. One form of reform that exists in Indonesian Criminal Law is the regulation of criminal law in the perspective of achieving justice for the improvement and recovery of conditions after criminal justice events and processes known as restorativejustice, which is different from retributive justice (emphasizing justice in retaliation) and restitutive justice (emphasizing justice in compensation). When viewed from the development of criminal law science and the nature of modern punishment, it has introduced and developed what is called the Doer-Victims Relationship approach. A new procedure that has replaced the action or actor approach or "daad-dader straftecht." Legal 
experts have introduced a formula for justice, especially in upholding human rights, that there are three aspects of the course to building a legal system in the context of modernization and legal reform, namely in terms of structure, substance, and culture, all of which are feasible to run correctly-integral, simultaneous, and parallel. ${ }^{1}$

Restorative Justice and Diversion are near related - restorative justice is the goal of implementing diversion in the Juvenile Criminal Justice System. Restorative justice is a diversion process. All parties involved in a specific criminal act jointly solve problems and create an obligation to make things better by involving victims, children, and the community to find solutions to improve, reconcile, and reassure that is not based on vengeance. The restorative justice approach concept is an approach that focuses more on the conditions of creating justice and balance for the perpetrators of criminal acts and the victims themselves. The procedural and criminal justice mechanisms that focus on punishment are transformed into a dialogue and mediation process to create an agreement on the settlement of criminal cases that is more just and balanced for the victim and the perpetrator.

Following the SPPA Law, Deliberation is carried out by involving children and their parents/guardians, victims and/or their parents/guardians, community counselors, professional social workers, representatives, and other involved parties to reach a diversion agreement through a justice approach restorative. The deliberation can also involve Social Welfare Workers and the Community. Mediation or dialogue, or consideration as an integral part of diversion to achieve restorative justice. Reviews are held in a family atmosphere, sincere. There should be no coercion and must pay attention to the victims' interests. The parts of victims are the rights of victims, or child victims must be considered proportionally. The child's welfare and the child's responsibility must also be considered so that the child is still given his rights. However, there is even guidance for his mistakes so that the child is not free from responsibility for implementing the Diversion agreement.

Diversion's success is expected because, with the success of diversion, restorative justice is realized. Diversion deals mark diversion's hit. A diversion agreement can take the form of a settlement with or without compensation, return to the parent/ guardian, participation in education or training at educational institutions or LPKS for a maximum of 3 (three) months or community service. The Diversion Agreement can also be made without the consent of the victim and/or the victim's family if the criminal act in the form of a violation, minor crime, crime without the victim, or the value of the victim's loss is not more than the local, provincial minimum wage. This is done by the investigator and the child and / or their family, and the social advisor can involve community leaders.

${ }^{1}$ Ridwan Mansyur. (2017). Keadilan Restoratif Sebagai Tujuan Pelaksanaan Diversi Pada Sistem Peradilan Pidana Anak. https://www.mahkamahagung.go.id/id/artikel/2613/keadilan-restoratif-sebagaitujuan-pelaksanaan-diversi-pada-sistem-peradilan-pidana-anak. Accessed 16 June 2020. 
Restorative justice is realized if the diversion is successful and the agreement has been fully implemented so that the child's case can be stopped. Termination of cases of children can be done at any level. With this diversion's success, children who face the law will avoid stigmatization, and children can naturally return to the social environment. The success factor of diversion is the willingness to agree between the perpetrator and the victim. It has implemented the agreement, while the factors that affect diversion's success depend on the victim if the victim does not agree to make peace. The victim or the victim's family does not agree to settle the case through diversion because they still think that punishment is retribution for the wrong that has been done.

Diversion is a crucial matter regulated by the SPPA Law because it aims to achieve peace between victims and children, resolve child cases outside the judicial process, prevent children from being deprived of liberty, encourage the community to participate, and instill a sense of responsibility in children. In the process of enforcing child criminal law, investigators, public prosecutors, and judges in seeking diversion must consider the categories of criminal acts, the child's age, the results of social research, and support from the family community environment. Moreover, a diversion agreement occurs when the consent of the victim and/or the victim's family and the willingness of the child and their family have been obtained, this shows that in the implementation of diversion, there must be a friendly discussion between the child and the victim to achieve the best interests of the child while still paying attention to justice for the victim. However, if the diversion fails, solving children's cases will be continued following the criminal justice process. It can be said that this diversion provides an alternative for law enforcement officials in solving juvenile issues without having to go through a criminal justice process to realize restorative justice.

The implementation of diversion in Indonesia is different from other countries, for example, in the Philippines. In the Philippines, all cases of children are carried out by diversion. ${ }^{2}$ The Philippines, in its legal regulations, can balance children's interests as perpetrators and children as victims in a balanced manner. This means that apart from thinking about the victims' claims, the State of the Philippines also thinks about the perpetrators' interests because, in whatever position, they are still human beings who are categorized as children who have unique characters who must be given protection. In Indonesia, diversion can only be attempted for criminal acts with the threat of less than 7 (seven) years and are not recidivists. ${ }^{3}$

As explained above, the Philippines applies a diversion process to all types of criminal acts committed by children, meaning that in every settlement of cases of

${ }^{2}$ Ni Putu Sri Utari. (2018). Diskriminasi Penerapan Diversi Terhadap Anak Yang Melakukan Tindak Pidana. Jurnal Kertha Wicara Vol. 7 No. 2 the Year 2018. Denpasar: Fakultas Hukum Universitas Udayana, p. 9

${ }^{3}$ Ibid, p.12 
children in conflict with the law, it always involves the perpetrator, the victim, the family of the perpetrator, and the victim as well as other interested parties. In this case, to collectively seek a settlement and agreement without being limited by the type or criminal threat being committed. The Philippines state indeed provides protection that prioritizes welfare for the best interests of the child. It is in line with the principles in the formation of the Juvenile Justice System in Article 2 of the SPPA Law, which concerns: protection, justice, non-discrimination, the best interests of children, respect for children's opinions, the survival and development of children, fostering and guiding children, proportional, deprivation of liberty and punishment as a last resort, and avoidance of retaliation, while the implementation of diversion in Indonesia appears only to protect children who commit criminal acts in individual acts because it is right in the explanation of Article 9 Paragraph (1) The SPPA Law explains that diversion is not intended to be implemented against perpetrators of serious crimes, such as murder, rape, drug trafficking, and terrorism who are punishable by crimes over 7 (seven) years.

Considering that the diversion effort itself does not necessarily reach an agreement between the parties, diversion can be successful and may fail, depending on the course of the parties' deliberations. If the diversion process is successful, then the case settlement process outside the criminal court has realized restorative justice. Still, when the diversion process fails, in the end, the settlement of juvenile cases is continued through formal criminal justice. Researchers assess that diversion is the right of every child, so it does not need to be limited. Children who have to be caught in narcotics, terrorism, rape, and other serious crimes also have the right to get access to diversion. At the very least, all children in conflict with the law are allowed to improve themselves and take responsibility for their actions, so that restrictions on the requirements for implementing diversion as in Article 7 Paragraph (2) of the SPPA Law and Article 9 Paragraph (2) of the SPPA Law need to be made other arrangements as alternatives carry out a diversion in advance of all types of criminal acts committed by children. Currently, diversion is a process of solving children's cases recognized internationally as the best and most effective way of resolving issues. ${ }^{4}$

Implementation of diversion as ruled in Article 9 Paragraph (2) of the SPPA Law, states a diversion agreement must obtain the consent of the victim and/or the victim's family, and the willingness of the child and his/her family, except for: a) Criminal acts in the form of violations; $b$ ) Minor criminal offense; c) Crime without victims; or d) The value of the victim's loss is not more than the local, provincial minimum wage value.

This means that for criminal acts except those excluded in that article, the obligation to be diversified only extends to the endeavor by law enforcers at each

${ }^{4}$ Marlina. (2010). Pengantar Konsep Diversi dan Restorative Justice dalam Hukum Pidana. Medan: USU Press, p. 61 
examination level. Diversion is compulsory to be pursued, but regarding whether diversion will be taken or not, it depends on the agreement of the perpetrator and the victim. In this case, it is evident that diversion in principle is mandatory but must be limited. From the comparative data between the State of Indonesia and the State of the Philippines, supported by several legal instruments regulating the principle of deprivation of liberty and punishment as a last resort, what is done by the Philippines is that every child case is carried out by a Diversion effort, reflecting the deprivation of freedom and punishment really as a last resort.

\section{CLOSING}

\section{Conclusion}

Diversion aims to avoid and keep children away from the judicial process to prevent stigmatization of children who conflict with the law. It is hoped that children can return to the social environment properly. The application of diversion in the Juvenile Criminal Justice System cannot be made in all cases of children. The application of diversion can only be carried out in children whose penalties are below 7 (seven years) or are not repeating the crime. Restorative justice is a diversion. If the child's case meets the requirements for diversion, the hope of restorative justice can be realized, namely by the success of a Diversion. Sometimes the child case does not meet the needs for diversion according to the SPPA Law, even though the child case leads to restorative justice because the child perpetrator and the victim have received a fair settlement by making peace and recovering to normal. By not passing the Diversion effort, the child is threatened with punishment so that it is not following the Principle of Deprivation of Independence and discipline as a last resort, because there are efforts that should be done or pursued, namely diversion but not because there are restrictions on diversion in the case of Children following Article 7 of the Law SPPA. If the Philippines' State of Indonesia does as has been done, namely, diversion is applied to every child case. Deprivation of liberty and punishment is the last resort.

\section{Recommendation}

It is recommended that the application of diversion in the case of a child can be made in every issue of a Child, there is no priority for diversion, does not look at the level of the criminal threat or the repetition of the criminal act of the child is high or low. The diversion that is carried out still considers the victims' interests because there is no success without the consent or agreement with the victims. Suppose the child's act is committed without a victim (such as a drug case). In that case, the government can form an integrated team to consider the child's actions and whether a restorative justice approach can be used. The child who is a criminal offender is also a victim of his/her environment. Restorative justice using diversion is applied to every child so 
that the Principle of Deprivation of Independence and Criminalization as a last resort is the last resort because it has gone through diversion. If the Diversion effort is not passed, then the deprivation of freedom and punishment is not the last resort because there are still restrictions on diversion.

\section{REFERENCES}

Undang-Undang Nomor 3 Tahun 1997 tentang Pengadilan Anak

Undang-Undang Nomor 11 Tahun 2012 Tentang Sistem Peradilan Pidana Anak

Barda Nawawi Arief. (2008). Bunga Rampai Kebijakan Hukum Pidana: (Perkembangan Penyusunan Konsep KUHP Baru): Edisi Pertama. Jakarta: Kencana Prenada Media Group.

M. Nasir Djamil. (2015). Anak Bukan Untuk Dihukum (Catatan Pembahasan UU Sistem Peradilan Pidana Anak Republik Indonesia). Jakarta: PT. Sinar Grafika.

Marlina. (2010). Pengantar Konsep Diversi dan Restorative Justice dalam Hukum Pidana. Medan: USU Press.

Ni Putu Sri Utari. (2018). Diskriminasi Penerapan Diversi Terhadap Anak Yang Melakukan Tindak Pidana. Jurnal Kertha Wicara Vol. 7 No. 2 the Year 2018. Denpasar: Fakultas Hukum Universitas Udayana.

Ridwan Mansyur. (2017). Keadilan Restoratif Sebagai Tujuan Pelaksanaan Diversi Pada Sistem Peradilan Pidana Anak. https://www.mahkamahagung.go.id/id/artikel/2613/ keadilan-restoratif-sebagai-tujuan-pelaksanaan-diversi-pada-sistem-peradilanpidana-anak.

Wagiati Soetedjo dan Melani. (2017). Hukum Pidana Anak. Bandung: PT. Refika Aditama. 